\title{
ŻRóDŁA
}

\author{
Danuta Bogdan
}

\section{TESTAMENT KATARZYNY HINTZMAN, CÓRKI BURMISTRZA DOBREGO MIASTA JERZEGO HINTZMANA, Z 20 LISTOPADA 1730 ROKU}

Życie i śmierć było postrzegane przez ludzi średniowiecza i czasów nowożytnych w sposób odmienny od dzisiejszego, odczuwano wówczas silnie kruchość życia i jego przejściowość na drodze do osiągniecia wiecznego zbawienia. Potęga śmierci dawała się odczuć zwłaszcza w czasie panującej zarazy. Jeden ze współezesnych kronikarzy dopatrywał się przyczyn drożyzny, która panowała w Gdansku w $1483 \mathrm{r}$. w tym, ze od dwudziestu lat nie było tu prawdziwego umierania („rechtes Sterben”) ${ }^{1}$. Przygotowaniem do „dobrej śmierci” było sumienne wypełnienie powinności religijnych oraz uregulowanie spraw doczesnych poprzez szczegółowe zapisy testamentowe.

Średniowieczne i nowożytne dyspozycje testamentowe kobiet docenione zostały w ostatnich latach nie tylko jako pierwszorzędne źródła historyczne, ale także jako wyraz kobiecej emancypacji i społecznej komunikacji minionych wieków². Częściej dyspozycje ostatniej woli składali mężczyźni, co wynikało z ich dominującej roli w rodzinie i występowania przy tej czynności prawnej w imieniu swoim i żony. Kobiety spisujące testamenty, choć pochodziły z różnych stanów, były zazwyczaj osobami samotnymi: pannami, wdowami lub po ślubach zakonnych. Wobec szczątkowego zachowania warmińskich ksiąg miejskich, testamenty pozostają nielicznymi źródłami, na których podstawie możemy próbować rekonstruować codzienne życie warmińskich kobiet minionych wieków³.

\footnotetext{
${ }^{1}$ C. Weinreich, Danziger Chronik, hrsg. v. Th. Hirsch und F. A. Vossberg, Berlin 1855, s. 29, 34, 85-87.

${ }^{2}$ Por. K. Pajcic, Frauenstimmen in der spätmittelalterlichen Stadt Testamente von Frauen aus Lüneburg, Hamburg und Wien als soziale Kommunikation, Würzburg 2013; dyspozycje testamentowe gdańszczanek z II poł. XV w odnotowuje artykuł B. Możejko, Gdański mieszczanin w obliczu śmierci, zapisy testamentowe z II połowy XV w (na podstawie ksiegi ławniczej), w: Mieszczanie, wasale, zakonnicy, Studia z Dziejów Średniowiecza, 2004, nr. 10, ss. 127-162 (przyp. 1, 2, literatura do problematyki testamentów).

${ }^{3}$ D. Bogdan, Testamenty szlacheckie i mieszczańskie z XVII wieku jako przejaw kultury prawnej Warmii, Komunikaty Mazursko-Warmińskie (dalej: KMW), 2004, nr 4, ss. 463-473; eadem, Testament starościny lidzbarskiej Anny Katarzyny Krakau z 22 stycznia 1742 roku i jego egzekucja, KMW, 2008, nr 4, ss. 461-476;
} 
Testament musiał zostać spisany z zachowaniem wymogów formalnych i treściowych. W protokole początkowym zawarte były „,inwokacja” $i$,intytulacja” określające osoby składające dyspozycję i przedstawiające okoliczności spisania testamentu. Część dewocyjna, określana „arengą, mogła składać się z dwóch części - pierwszej wskazującej na nieznaną godzinę śmierci i na pragnienie osiągnięcia zbawienia oraz drugiej, błagalnej, nazywanej „apprecatio”, w której wzmacniano decyzje odnoszące się do dyspozycji testamentowych. Indywidualne sformułowania, wzmacniające zamiar spisania testamentu, określane były jako „promulgatio”. Obligatoryjne potwierdzenie stanu zdrowia umysłowego osoby składającej dyspozycję ostatniej woli i podkreślenie faktu jej dobrowolności mogło wystąpić w początkowej lub końcowej części dokumentu. Najważniejszą częścią każdego testamentu była dyspozycja majątkowa uwzględniająca też w sposób szczegółowy regulację długów. W końcowej części testamentu mogła ponownie pojawić się „arenga”, w której testatorzy odwoływali się do Boga. Wreszcie protokół końcowy zawierał informacje o miejscu i czasie spisania dokumentu, a pod nim znajdowały się pieczęcie i podpisy świàdków ${ }^{4}$.

23 stycznia 1731 r.w Dobrym Mieście miało miejsce niezwykłe wydarzenie. Do mieszkania córki dawnego burmistrza dobromiejskiego, Georga Hintzmana, szześćdziesięcioośmioletniej, ciężko chorej Katarzyny Hintzman, wezwany został w celu potwierdzenia spisanego już wcześniej testamentu wysoki rangą notariusz. Był to posiadający tytuł notariusza publicznego Stolicy Apostolskiej Franciszek Ignacy Herr (Publicus Sanctae Authorithatae Apostolicae Notarius), jednocześnie dziekan kapituły dobromiejskiej ${ }^{5}$.

O samej testatorce wiemy bardzo niewiele. Jerzy Hintzman i jego małżonka Dorota ochrzcili w Dobrym Mieście siedmioro dzieci, wśród nich 1 października 1661 r. córkę Elżbietę , a 24 kwietnia 1663 r. interesującą nas tutaj córkę Katarzynę - autorkę publikowanego niżej testamentu ${ }^{7}$. Katarzyna Hintzman została odnotowana 15 sierpnia 1712 r. jako chrzestna w Świątkach ${ }^{8}$.

${ }^{4}$ Przegląd literatury dotyczącej testamentów patrz B. Popiołek, Testamenty staropolskie jako źródto do historii mentalności XVII i XVIII wieku, Kraków 2009. Analiza wewnętrznego układu treści testamentów przedstawiona została we wstępie edycji Testamenty szlachty Prus Królewskich z XVII wieku, oprac. i wyd. J. Kowalkowski, W. Nowosad, Warszawa 2013.

${ }^{5}$ Słownik Biograficzny Kapituły Kolegiackiej w Dobrym Mieście, Olsztyn 1999, s. 61. Herr Franciszek Ignacy, zm. w Dobrym Mieście w 1747, od 1726 dziekan kapituly dobromiejskiej, a od 1733 r. jej prepozyt.

${ }^{6}$ Archiwum Archidiecezji Warmińskiej w Olsztynie (dalej: AAWO), Archiwa parafialne (dalej: Ap), Dobre Miasto E 215, s. 171: „[Parentes] Georgius Hintzman propola, Dorothea coniux. [Infans] Elisabeth. [Patrini] Sp[ectabilis] D[ominus] Stanislaus Berenth scabinus cum Elizabeth Sp[ectabilis] D[omini] Balthazaris Schultz viri consularis coniuge”.

${ }^{7}$ Ibidem, s. 182: „[Patrini] D[ominus] Laurentius Dittloff ciuis cum Catharina D[omini] Gregorii Otth ciuis conjuge" (Katarzyna - podobnie jak wcześniej jej starsza siostra Elżbieta i później młodsza Anna - otrzymała na chrzcie imię na cześć matki chrzestnej).

${ }^{8}$ AAWO, Ap, Świątki E 242, s. 73: „Catharina filia p[iae] d[efuncti] Georgii Hintzman praeconsulis Guttstadiensis”. 
O rodzinie testatorki dowiadujemy się z braniewskich i lidzbarskich ksiąg metrykalnych. Ojca Jerzego, burmistrza Piotra Hintzmana, odnajdujemy w Lidzbarku Warmińskim, natomiast jego przodków tam nie ma i wszystko wskazuje na to, że wywodzili się ze Starego Miasta Braniewa. W Starym Mieście Braniewie 16 września 1591 r., 8 lutego1600 r. i 15 stycznia 1615 r. na ślubnym kobiercu stawał trzykrotnie Jakub Hintzman/Hinczman ${ }^{9}$, którego przy pierwszej ceremonii ślubnej określono: „Jacobus Hintzman Tomae Hintzmanss filius antiquae civitatis [Brunsbergensis]"10.

Do władz Starego Miasta Braniewa przynależało tylko kilkanaście rodzin i przebicie się do ścisłej elity władzy osób spoza określonego kręgu nie było łatwe. Wydaje się, że Piotr Hintzman nie widział w Braniewie większych szans na awans w radzie miejskiej i najprawdopodobniej podjął odważną decyzję o przeniesieniu się do stołecznego Lidzbarka. Nastąpiło to zapewne w końcu lat dwudziestych XVII w., o czym świadczy fakt odnotowania go w lidzbarskiej księdze chrztów 1 września 1630 r. Tego dnia „Petrus Hintzman cantor Heilsbergensis” trzymał do chrztu Michała Elerta, syna Jerzego i Anny ${ }^{11}$. W Lidzbarku, najpewniej jesienią $1630 \mathrm{r}$. lub wczesną wiosna $1631 \mathrm{r}$, Piotr Hintzman ożenił się z Elżbieta, której nazwiska panieńskiego nie znamy. Miał z nią troje dzieci: 14 marca 1632 r. ochrzczono Piotra juniora ${ }^{12}, 1$ marca 1633 r. - interesującego nas Jerzego ${ }^{13}$ i 17 czerwca 1635 r. - Annę $e^{14}$.

Piotr Hintzman wszedł do rady miejskiej Lidzbarka przed 21 czerwca 1658 r. (został wówczas odnotowany jako sędzia miejski - judex, Stadtrichter) ${ }^{15}$ i doszedł do godności burmistrza. Piastując ten urząd zmarł 21 czerwca 1687 r. $^{16}$

Z kolei najstarszy syn Piotra Hintzmana, wspomniany Jerzy, poślubił córkę rajcy dobromiejskiego (późniejszego burmistrza) i przeniósł się do Dobrego Miasta, koronując swą karierę godnością burmistrza tego miasta.

Tak więc w Dobrym Mieście, parafii panny młodej, 26 września $1660 \mathrm{r}$. odbył się ślub: „[Contrahentes] Georgius Hintzman Sp[ectabilis] D[omini] Petri Hintzman viri consularis Heilsb[ergensis] filius cum Dorothea Sp[ectabilis] $\mathrm{D}$ [omi]ni Gregorii Steffen viri consularis Gudstadiensis filia. [Testes] Perillustris ac Adm[odum] R[everendus] D[omi]nus [Zacharias Joannes] Szulc [Szolc] can-

${ }^{9}$ AAWO, Ap, Braniewo E 76, k. 94, 117v, 163, 175v.

${ }^{10}$ Niezachowanie się braniewskiej księgi chrztów z lat 1589-1629 oraz brak księgi zmarłych z końca XVI i z XVII stulecia nie pozwala stwierdzić autorytatywnie, czy te trzy śluby zawarł ten sam Hintzman „Jakub, syn Tomasza”.

${ }^{11}$ AAWO, Ap, Lidzbark Warmiński E 251, k. 212.

${ }^{12}$ Ibidem, k. 217.

${ }^{13}$ Ibidem, k. 220v - chrzestnymi Jerzego byli: „Simon Basner, Margarete Laurentii Tamsons uxor”.

${ }^{14}$ Ibidem, k. 228v.

${ }^{15}$ AAWO, Archiwum Kapituły, Rep. 128, VIII 48, bez paginacji.

${ }^{16}$ AAWO, Ap, Lidzbark Warmiński E 262, k. 1v . 
cellarius Heilsbergensis, Clarissimus ac Adm[odum] R[everendus] D[omi]nus Albertus Bogurski praepositus Collegii Gudstadiensis"17.

To typowy przykład zacieśniania więzów rodzinnych w ramach górnych warstw patrycjatu miast warmińskich w czasach nowożytnych.

$\mathrm{Na}$ to, że Jerzy Hintzman urząd burmistrza dobromiejskiego sprawował od 1677 r. wskazują informacje zawarte w księdze Bractwa NMP, którego członkami byli Jerzy i Dorota Hintzmanowie oraz ich dzieci po osiągnięciu wieku kilkunastu lat. Kiedy członkinią Bractwa została 2 lutego 1677 r. Elżbieta Hintzman, podano przy jej nazisku, że była „córką burmistrza” ${ }^{18}$. Podobnie „synem burmistrza” nazwano Jana Hintzmana, a „córką burmistrza” Annę Hintzman, przyjętych do Bractwa NMP odpowiednio 8 września 1685 i 2 lutego 1690 r. ${ }^{19}$

W księdze brackiej odnotowano daty roczne zgonów żony burmistrza Doroty $(1691)^{20}$ i burmistrza Jerzego Hintzmana/Hyntzmana (1695) ${ }^{21}$.

Katarzyna, autorka publikowanego testamentu, zmarła 3 lutego $1731 \mathrm{r}^{22}$

Testamentariuszka nie chciała wcześniej ujawniać szczegółów aktu swojej ostatniej woli, dlatego poprosiła notariusza o zachowanie dyspozycji testamentowej w tajemnicy aż do jej śmierci. Miało to zapobiec wszelkim naciskom i ewentualnym pretensjom ze strony przyjaciół.

Katarzyna swoją ostatnią dyspozycję testamentową wyraziła z własnej i nieprzymuszonej woli 20 listopada $1730 \mathrm{r}$. Jak wynika z treści testamentu, uczyniła to będąc całkowicie świadoma i pozostając w pełni władz umysłowych. Testament Katarzyny Hintzman spisany został w formie osobnego dokumentu i uznany za obowiązujący we wszystkich punktach, artykułach i klauzulach ${ }^{23}$.

Dyspozycja testamentowa Katarzyny Hintzman jest bardzo prosta w swojej wewnętrznej strukturze. Brak tu też rozbudowanej części religijnej, która ogranicza się w zasadzie do wezwania: „In nomine Domini Amen”. Po tym następuje

${ }^{17}$ AAWO, Ap, Dobre Miasto E 222, s. 84.

${ }^{18}$ Ibidem, k. 25v. Wcześniejsze zapiski dotyczące Jerzego Hintzmana jako świadka na ślubach zawartych w Dobrym Mieście 20 XI 1667 r., 12 I 1670 r. i 10 II 1675 r. określają go jako „vir consularis”, a późniejsza od tu wskazanej - z 24 X 1677 r. - nie odnotowuje funkcji Jerzego Hintzmana (ibidem, Dobre Miasto E 222, s. 114, 124, 146 i 157). Dla porządku można dodać, że w aktach wizytacyjnych z 1681 r. również zapisano: „Georgius Hintzman consularis" - AAWO, Archiwum Biskupie (dalej: AB), B 77, k. 7.

${ }^{19}$ AAWO, Ap, Dobre Miasto 56, k. 27 i 28. Brak informacji, że członkami Bractwa byli Jerzy Hintzman junior (rocznik 1666) i Grzegorz Hintzman (rocznik 1671), świadczy o tym, że ci synowie Jerzego seniora i Doroty zmarli w dzieciństwie.

${ }^{20}$ Ibidem, k. 109.

${ }^{21}$ Ibidem, k. 114v.

${ }^{22}$ AAWO, Archiwum Kapituły Dobromieejskiej, Dok. D. M. J 43c, k. 1.

${ }^{23} \mathrm{Na}$ Warmii korzystano zapewne z kancelaryjnych wzorców dyspozycji testamentowych. Przykład późniejszego wzorca: AAWO, AK, V 20/I, Liber Processum ab Anno Domini 1685 ad Annum 1718 - wzorzec testamentu z czasów biskupa Załuskiego z ok. 1707/1708 r., k. 84-87v. 
krótki wstęp informujący o czasie, miejscu i okolicznościach spisania testamentu, a następnie szczegółowe rozporządzenie majątkowe wraz z wyliczeniem wysokości długów wobec kolejnych wierzycieli. Notariusz wraz z dokonaniem zapisu testamentowego sporządził też spis dóbr ruchomych.

W testamencie za najpilniejszą czynność Katarzyna uznała spłacenie ciążących na niej długów, które opiewały łącznie na kwotę 113 grzywien ${ }^{24} 19$ gr. Największą sumę winna była wdowie Zimmermann ${ }^{25}$, gdyż wraz z obrachunkiem kosztów zakupu drewna wynoszących 7 grzywien 4 gr, na dzień św. Marcina (11 XI) 1730 r. pozostawał dług w wysokości 37 grzywien 16 gr.

Wśród innych wierzycieli Katarzyny znaleźli się wysocy urzędnicy miejscy: rajca [Joannes] Filitz ${ }^{26}$, wobec którego dług wynosił 8 grzywien 6 gr, rajca [Peter] Wagner ${ }^{27}$, któremu winna była 8 grzywien 11 gr oraz majstrowie: sukiennik Joseph Bornek, któremu powinna oddać 12 grzywien i piekarz Joannes Thiel 5 grzywien 14 gr.

Zamieszkującemu w Cerkiewniku (Minsterberg) bratu Urszuli - kucharki pozostającej w służbie kapituły dobromiejskiej - Katarzyna dłużna była 14 grzywien 2 gr. Inni wierzyciele Katarzyny Hintzman to Catharina Grünhoff (14 grzywien) oraz niejaka Nickels z Chałupek (13 grzywien $10 \mathrm{gr}$ ).

Po uregulowaniu długów Katarzyna zatroszczyła się o swój godny pochówek w dobromiejskim kościele kolegiackim, przeznaczając na pogrzeb 150 grzywien oraz dodatkowo 100 grzywien na wykonanie dekoracji we wnętrzu tego kościoła.

W testamencie nie zabrakło też licznych donacji na inne instytucje kościelne. Pozostający w tym czasie w budowie dobromiejski kościół św. Mikołaja wsparła ona kwotą 50 grzywien. Kolejne fundacje Katarzyny Hintzman dotyczyły sanktuariów pielgrzymkowych: kaplicy w Międzylesiu (Schönwiese) i Krośnie (Crossen), którym zapisała po 50 grzywien. Katarzyna wiodła samotne, pobożne życie i nie pominęła w swych fundacjach warmińskich konwentów zgromadzenia katarzynek, przeznaczając dla klasztorów w Ornecie i Lidzbarku po 100 grzywien $^{28}$.

${ }^{24} 1$ grzywna pruska (Mark) $=20 \mathrm{gr}$.

${ }^{25}$ Być może żona dobromiejskiego szewca Laurentiusa Cimmermana - AAWO, Ap, Dobre Miasto 31, k. 63.

${ }^{26}$ Joannes Filitz rajca w latach 1728-1742. AAWO, Ap, Dobre Miasto 24, s. 170, 172-180, 182, 183, 185 , 187-189); od 11 VI 1736 burmistrz (AB, A 31, s. 251).

${ }^{27}$ Rajca 27 XI 1732. AAWO, Ap, Dobre Miasto E 223, s. 294

${ }^{28}$ W swym sprawozdaniu o stanie diecezji do Rzymu z 2 XII 1771 r. bp Ignacy Krasicki wykazał, że siostry ze zgromadzenia św. Katarzyny założonego przez bp. Marcina Kromera posiadały na Warmii cztery domy: w Braniewie, Ornecie, Lidzbarku i Reszlu, a w każdym z nich miało przebywać po dwadzieścia kobiet. Co trzy lata odbywały się wybory przełożonej wszystkich czterech domów. I choć reguła zakonu nie została przez Kościół zatwierdzona i siostry składały tylko śluby proste, to jednak odznaczały się wysokim poziomem życia religijnego. Por. G. Śliwińska, Dzieje Zgromadzenia Sióstr Świętej Katarzyny Dziewicy i Męczennicy, Olsztyn 1998; AAWO, AB, A 63, k. 132-141; Druk: Sprawozdanie Ignacego Krasickiego do Rzymu o stanie diecezji, Frombork 2 XII 1771, w: Ignacy Krasicki na Warmii 1766-1772. Przekazy źródłowe, cz. II 1769-1772, oprac. A. Szorc, nr 160, s. 212, Olsztyn 2002; E. M. Wermter, Die Anfänge der Kongregation der Schwestern von der heiligen Jungfrauen und Martyrin Katharina und ihre Gründerin Regina Protmann, w: Wichmann-Jahrbuch, N. F. 2, 32-33, 1992/1993, ss. 79-87. 
Swoim wsparciem finansowym Katarzyna Hintzman objęła też bernardyńskie klasztory w Barczewie (50 grzywien) oraz w Stoczku (36 grzywien). Ponadto kaplicy lidzbarskiego klasztoru katarzynek zapisała mały miedziany obrazek, na którym widniała $\mathrm{z}$ jednej strony okrągła płaskorzeźba Maryi z Dzieciątkiem, a z drugiej - św. Michała ${ }^{29}$. Dla kaplicy orneckiego klasztoru katarzynek przeznaczyła także przedstawienie Maryi z Dzieciątkiem, a dla kaplicy w Międzylesiu dwa obrazki Chrystusa i Maryi.

Dalej w testamencie znajdujemy zapisy na rzecz osób prywatnych, zapewne najbliższych krewnych i przyjaciół Katarzyny. Dla nich przeznaczyła większą część swych ruchomości, głównie przedmioty z wyposażenia gospodarstwa domowego, mające większą wartość pamiątkową niż materialną.

I tak wymieniony tylko z nazwiska Gerigk ${ }^{30}$ miał otrzymać 50 grzywien oraz kasetkę i dwa cynowe półmiski, a tokarzowa Ertman 50 grzywien i tygielek. Dalej po 30 grzywien darowała: ławnikowi [Gregoriusowi] Ott ${ }^{31}$, majstrowi Dittloffowi ${ }^{32}$, żonie Józefa Langa i pannie Katarzynie Grünhoff. Gertruda Böhm dostała 12 grzywien, a niejaki „Heer Kessel" dostał wielkie wiadro i tygielek. Najhojniej obdarowana została nieznana z nazwiska, pochodząca z Zerbunia w komornictwie jeziorańskim, kobieta określona w dokumencie jako „Muhmen Sophiae von Saurbohm", której testatorka zapisała 60 grzywien oraz trzy łoża, poszwy pościelowe, trzy cynowe półmiski i lnianą odzież.

Zgodnie z obowiązującym zwyczajem, w czasie pogrzebu rozdawano też datki wśród ubogich. Katarzyna nie zapomniała o jałmużnie, ofiarując biednym 12 grzywien.

Testatorka poleciła dziekanowi kapituły dobromiejskiej Franciszkowi Ignacemu Herrowi powołanie przy dobromiejskim kościele kolegiackim fundacji modlitewnej za swoją duszę oraz dusze jej rodziców i krewnych. Chciała też wspomóc finansowo te fundacje modlitewne parafii dobromiejskiej, których zasoby finansowe wyczerpały się i nie pozwalały na kontynuację zobowiązań wobec zmarłych.

Potwierdzenie dyspozycji ostatniej woli Katarzyny Hintzman nastąiło w obecności godnych świadków. Wysoki urząd publiczny ojca Katarzyny wpły-

${ }^{29}$ „dass kleine kupfferne Bildschen, darauf die Teller Seeligste Jungfrau mit dem Kindlein Jesus auf einer Seiten und der S. Michael auf der anderen Seiten".

${ }^{30}$ Być może Józef Michał Gerick, od 1729 r. wikariusz dobromiejski. A. Kolberg, Zur Verfassung Ermlands beim Übergang unter die preussische Herrschaft, Zeitschrift für die Geschichte und Altertumskunde Ermlands, 1894, Bd. 10, s. 55.

${ }^{31}$ Gregorius/Georgius Otto/Oth, ławnik od 6 IX 1726, AAWO, AB, A 28, ss. 278-279, starszy ławy (scabinorum praefectus) 11 VI 1736 (AB, A 31, s. 254); zmarł jako Schöpenmeister między 1738 a 1741 r. (Ap, DM 56, k. 115v).

${ }^{32}$ Zapewne miejscowy płatnerz: Joannes civis lorifex, AAWO, Ap, Dobre Miasto 31, k. 61. 
nął na wybór egzekutorów testamentu. Byli to: Józef Gerigk, beneficjariusz jej testamentu, oraz Sylwestr Geritz - burmistrz dobromiejski ${ }^{33}$, Testamentariuszka wyraziła też życzenie, aby spisujący dokument notariusz Franciszek Ignacy Herr trzymał się ściśle uczynionej przez nią dyspozycji. Pod testamentem znalazł się podpis Franciszka Ignacego Herra, który włączył opieczętowany testament Katarzyny Hintzman do akt notariatu.

Katarzyna Hintzman zmarła 3 lutego 1731 r., a 27 kwietnia 1731 r. w Smolajnach uczyniony przez nią zapis testamentowy przedłożony został do zatwierdzenia bp. Krzysztofowi Andrzejowi Janowi Szembekowi i bliżej nieznanemu duchownemu „Domino Lourdinerio” ${ }^{34}$ w obecności dwóch dobromiejskich rajców, a także reprezentantów ławy i notariusza. W tym wypadku testament własnoręcznie poświadczył notariusz Kurii Biskupiej - Antonius Ignatius Hoffmann $^{35}$. Tego dnia w Smolajnach zjawili się też spadkobiercy: w imieniu kościoła kolegiackiego dziekan kapituły dobromiejskiej i tutejszy proboszcz Franciszek Ignacy Herr oraz krewni zmarłej Katarzyny Hintzman. Przyczyną stawienia się stron przed biskupem był fakt zgłoszenia $w$ terminie prawnym ogłoszonym w litteris cridae ${ }^{36}$ roszczeń do majątku po zmarłej.

Biskup, po wysłuchaniu stron, stwierdził, że choć prawomocność dyspozycji ostatniej woli Katarzyny Hintzman, zwłaszcza jej zapisy na fundacje pobożne, została przez krewnych podważona, to jednak testament spełnia wszystkie wymogi prawne, aby mógł być uznany za ważny i obowiązujący, gdyż spisany został przez notariusza publicznego Stolicy Apostolskiej, z udziałem wystarczającej reprezentacji, czyli dwóch świadków, zaś dalsi krewni obu płci według prawa chełmińskiego zostali obdarowani przez testamentariuszkę legatami. Biskup podkreślił też, że prawo chełmińskie nie ogranicza zapisów na cele pobożne i dlatego testament Katarzyny Hintzman zatwierdził i potwierdził pieczęcią odciśniętą w czerwonym wosku.

Po śmierci Katarzyny Hintzman egzekutorzy testamentu musieli rozstrzygnąć, co się komu należy i sporządzić spisy i inwentarze pozostawionego majątku zarówno w gotówce, jak i w ruchomościach. W inwentarzu wymieniono więc: Iniane piernaty, poduszki, bieliznę pościelową, prześcieradła, drewnia-

${ }^{33}$ Zmarł przed 11 VI 1736 jako burmistrz, AAWO, AB, A 31, k. 251.

${ }^{34}$ Zob. Aneks źródłowy, dokument Nr 2.

${ }^{35}$ Antoni Ignacy Hoffman/Hofmann (1699-1760), 17 VI 1724 wikariusz katedralny we Fromborku, 27 IV 1731 notariusz biskupi, 11 IV 1733 inwestytura na honorowego kanonika dobromiejskiego, instalowany 12 IV 1731. Po śmierci Jana Adalberta Heinicka został rzeczywistym kanonikiem dobromiejskim, a od $30 \mathrm{X}$ 1749 dziekanem tej kapituły. A Kopiczko, Duchowieństwo katolickie Diecezji Warmińskiej w latach 1525-1821, cz. 2: Słownik, Olsztyn 2000, s. 123.

${ }^{36}$ Tzw. litterae cridae przybijane na bramie lub drzwiach kościołów były powiadomieniem o możliwości zgłaszania się uprawnionych do spadku po zmarłym i jego wierzycieli. 
ne łóżka, 9 obrazków, 4 skrzynie, trójkanciasty kufer, 2 drewniane krzesła, ławę, krucyfiks oraz pozostawione zboże - 3 korce pszenicy i 3 korce żyta.

Egzekutorzy dokonali spieniężenia majątku poza tą jego częścią, która podlegała zapisom testamentowym. Najwięcej uzyskano ze sprzedaży gruntów, a mianowicie $800 \mathrm{fl}$ - - za pół łana sprzedanego burmistrzowi Dobrego Miasta Sylwestrowi Geritzowi oraz ze sprzedaży Dorothei Behrend położonego na prawym brzegu Łyny niedaleko Dobrego Miasta pola Lindenborn/Lindenbrunnen ${ }^{37}$. Mniejsze kwoty przyniosła sprzedaż przedmiotów codziennego użytku, które zakupili: Gregorius Ott 9 fl. 3 gr, Joseph Lang 17 fl. 17 gr i Joannes Dittlof $26 \mathrm{fl} 3 \mathrm{gr}$ oraz wdowa Zofia z Zerbunia $10 \mathrm{fl} .15$ gr. Ponadto za starą prostą suknię otrzymano 24 gr, za obcęgi 6 gr, a za aromatyczne „korzenie” 6 gr. Po śmierci Katarzyny znaleziono przy niej pieniądze w kwocie 7 fl. 191/2 gr. Ogółem suma wszystkich przychodów ze spieniężenia ruchomości i nieruchomości wyniosła $932 \mathrm{fl}$. 23 gr 9 denarów.

Z tych pieniędzy kwotą $123 \mathrm{fl} .17$ gr 9 denarów zaspokojono roszczenia wiérzycieli, wśród ktôrych znaleźli się: kapelan dobromiejski Piotr Elert, wdowa Zimmerman, Joannes Filitz, Petrus Wagner, sukiennik Joseph Bornek, piekarz Joannes Thiel, gospodarz z Cerkiewnika Adalbert German, Catharina Grünhof, Magdalena z Chałupek (Hausberg) ${ }^{38}$, wdowa Catharina Rautenberg, wdowa po Andreasie Schipperze, Joannes Dittloff (w ramach wynagrodzenia za oszacowanie łanów), Joannes Wagner, wdowa Dorothea Berendt, Joannes Merten, wdowa Perikett, wdowa Ertman.

Egzekucja testamentu Katarzyny przebiegła zgodnie z wolą testatorki, choć nieznaczne różnice wynikały z tego, że zapisane legaty podane zostały we florenach, zaś rozliczenie nastąiło w grzywnach pruskich. I tak niektóre sumy dawały dokładne przeliczenie $z$ jednych jednostek na drugie, np. pochówek wyznaczony na 100 fl., to dokładnie 150 grzywien, ale już kwota za ornat określona na 66 fl. i 20 gr powinna być przeliczona na 99,3 grzywny, a faktycznie zaokrąglono ją do 100, podobnie na oratorium św. Mikołaja zapisano $33 \mathrm{fl}$. i 10 gr, co w przeliczeniu stanowiło 49,65 grzywny, a przekazano nieco zawyżoną kwotę 50 grzywien. W innym wypadku zamiast zaokrąglić wysokość legatu w górę, zaniżono jego wymiar, np. Gertruda Böhm miała otrzymać 12 fl. (360 gr), a otrzymała tylko 12 grzywien ( $240 \mathrm{gr})$.

Ogółem na realizację zapisów testamentowych wydatkowano kwotę $793 \mathrm{fl}$. 23 gr 9 denarów, w tym znalazło się 5 fl. 6 gr dla pisarza za zatwierdzenie testa-

\footnotetext{
${ }^{37}$ Lindenbrunn leżały na południe od Dobrego Miasta, a na północ od przedmieścia Chałupki, 2 łany w Lindenbrunn przeznaczone były na ogrody mieszczan.

${ }^{38}$ Chałupki - w czasach nowożytnych osada leżąca na południe od Dobrego Miasta, która z czasem stała się jego przedmieściem określanym jako Przedmieście Jeziorańskie lub Olsztyńskie.
} 
mentu oraz 1 fl. podatku łanowego, który trzeba było jeszcze zapłacić jako kontrybucję od połowy łanu ziemi.

Różnica pomiędzy realizacją zapisów testamentowych a przychodami uzyskanymi ze sprzedaży ruchomości po śmierci Katarzyny Hintzman wyniosła 139 fl. i przeznaczona została na powiększenie beneficjów kolegiaty dobromiejskiej (66 fl. 20 gr na rzecz Beneficium Steinsoniani oraz 40 fl. 20 gr na rzecz Beneficium Knoblochiani). W zamian kanonicy dobromiejscy mieli modlić się za duszę testatorki i odprawiać cztery msze św. w roku za spokój jej duszy, jej rodziców i krewnych.

Egzekutorzy testamentu odpowiedzialni za zorganizowanie ceremonii pogrzebowej dokonali też podsumowania związanych z tym wydatków. W okresie przedpogrzebowym, czyli przygotowawczym do pogrzebu (od 4 do 8 lutego 1731 r.) śpiewano i odprawiano egzekwie za duszę zmarłej i układano kazania i mowy żałobne. W tym też czasie obowiązywał zwyczaj odwiedzania zmarłego, wokół którego zapalano świece (zapłacono za nie 6 gr). Gości podejmowano też jedzeniem, za które w okresie przed pogrzebem zapłacono 4 fl. 19 gr. W tym czasie zakupiono 7 funtów wołowiny (około $32,74 \mathrm{~kg}$ ) po 2 gr za funt $^{39}$, chleb za 3 gr, ćwiertnię (Viertel) ${ }^{40}$ cielęciny za 9 gr. 7 lutego zjedzono ryby (certe) ${ }^{41}$ za 6 gr, zaś 8 lutego za 12 gr, na chleb wydano 6 gr, na mleko 2 gr, a na oliwę 3 gr. Jeszcze przed pogrzebem wypito też 20 sztofów (około 28 litrów) ${ }^{42}$ piwa, które kosztowało 2 fl.

Inne wydatki dotyczyły już organizacji samego pogrzebu. Z rachunków wynika, że pogrzeb córki burmistrza, określany w baroku jako pompa funebris, musiał mieć bogatą oprawę. Pochód żałobny ciągnął zapewne przez całe miasto do kościoła parafialnego, który biciem w dzwony oznajmiał o rozpoczęciu ceremonii żałobnej. Na pogrzeb zakupionych zostało wiele świec i wykorzystano wiele rekwizytów mających uświetnić kondukt żałobny ${ }^{43}$. W organizację tego pogrzebu szczególnie zaangażowany był pierwszy cech rzemieślniczy Dobrego Miasta - szewców. Katarzyna była po ojcu jego członkinią, gdyż jej nazwisko wpisane zostało do księgi zmarłych tego cechu, za co zapłacono 6 gr. Była też członkinią dobromiejskiego Bractwa Różańcowego i Bractwa Bożego Ciała.

Bezpośrednio przed pogrzebem zebrano czeladników szewskich i dano im 2 sztofy gorzałki warte $1 \mathrm{fl}$. 20 gr. Tym, którzy mieli nieść kartusze i mary przekazano jeszcze 6 półachtli4 ${ }^{44}$ piwa po 15 gr każdy. Trumna ozdobiona była kulami, za które zapłacono 27 gr.

\footnotetext{
${ }^{39} 1 \mathrm{Pfund} /$ funt $=467,622$ gr.

${ }^{40} 1$ Viertel $=4$ Metzen/garnce $=13,680$ litra.

${ }^{41}$ Ryba z rodziny karpiowatych.

${ }^{42} 1 \mathrm{Stoff} /$ sztof $=13831-1,428$ litra.

${ }^{43} \mathrm{Za}$ wosk na świece zapłacono ogółem 16 fl. 221/2 gr.

${ }^{44} 1$ Achtel to $1 / 8$ beczki, w zależności od regionu od 35-90 litrów.
} 
Cechowi szewców za wykonanie kartuszy (Kartitzen) dano funt wosku wart 1 fl. oraz pół beczki (tuny - około 56,17 litra) piwa. Zakupiono też 6 łokci $(34,68 \mathrm{~m})^{45}$ czarnego sukna po 6 gr za łokieć. Przygotowanie grobowca kosztowało 10 fl., a grabarzowi dano $3 \mathrm{fl}$. Za uroczyste zapraszanie gości i obsługę ceremonii Schönfeltowej wypłacono 12 fl., a pachołek woźnicy/woźnica (Wagenknecht), zapraszający gości, dostał 6 gr. Bractwu Różańcowemu za kartusze dano 1 funt wosku wart $1 \mathrm{fl}$. Bractwu Bożego Ciała, czyli Strzeleckiemu, wypłacono 15 gr za pół funta wosku oraz 6 gr za wpis Katarzyny Hintzman do księgi zmarłych tego Bractwa.

Za szycie i czyszczenie wyprawy pogrzebowej Katarzyny Hintzman niejakiemu Titusowi zapłacono $21^{1 / 2}$ gr. Za odprawienie mszy św. pogrzebowej 18 gr, wreszcie 8 gr rozdano ubogim. Po spłaceniu jeszcze długu 25 fl. i 6 gr wobec Zimmermanowej okazało się, że na opłacenie pogrzebu zabrakło $42 \mathrm{fl}$. i $29 \mathrm{gr}$. Nie było też pieniędzy na zaspokojenie pozostałych wierzycieli. W tej sytuacji egzekutorzy testamentu zdecydowali się na spłacenie wierzycieli pozostałymi ruchomościami.

I tak Herr Joseph Lang przyjął 2 tóżka i 4 poduszki warte $7 \mathrm{fl}$., durszlak za 12 gr, szklanki za 15 gr oraz $23 / 4$ korca pszenicy wartej 4 fl. 28 gr i $1 \frac{1}{2}$ denara, 1 ruszt za 18 gr, powłoczkę na kołdrę za $18 \mathrm{gr}$, lusterko za $6 \mathrm{gr}$, stary kołowrotek za 24 gr, mosiężny uchwyt za 6 gr, 1 ławę za 15 fl. 71/2 gr, 1 płaszczyk za 2 fl. 91/2 gr.

Majster Dittlof wziął futro za $3 \mathrm{fl}$. oraz surdut i czarną koszulę za 9 fl., kolorową kamizelkę z rękawami wartą 15 gr, tygielek za 18 gr, czarne sukno za 1 fl. 15 gr, moździerzyk za 3 fl., cynowy ubijak do masła za 21 gr, duszę do żelazka i bolce za $18 \mathrm{fl}$. 9 gr. A ponadto oblamowaną czapkę za 3 fl., drewniane łoże za 1 fl. 24 gr, bańkę za 9 gr, szczypce do ognia za 12 gr. Ogółem otrzymał on w rzeczach równowartość 25 fl. 9 gr oraz 24 gr za 4 funty talku.

Herr Otto przyjął w gotówce $1 \mathrm{fl}$. $15 \mathrm{gr}$, latarnię za $18 \mathrm{gr}$, faskę ${ }^{46}$ do wina i wody, oprócz 4 cynowych łyżek, za 18 gr, srebrny medalik (Agnus Dei) za 1 fl., 2 korce żyta po $1 \mathrm{fl}$. za korzec, 2 beczki (półtuny) i 2 drewniane krzesła za $1 \mathrm{fl}$., starą skrzynkę za 2 fl., kufer z okuciami za $1 \mathrm{fl} .15$ gr. Potem dodano mu jeszcze $20 \mathrm{fl}$.

Wreszcie Herr Geritz dostał 2 sztofy kminku po 3 gr za sztof.

Nieznana z nazwiska Anna otrzymała niebieską spódnicę wartą $24 \mathrm{gr}$, a Herr Wessler krowie wędzidła warte 6 gr.

Panią z Zerbunia spłacono kwotą 23 fl. i 15 gr, ale przyjęła jeszcze poduszki, które były mocno podniszczone, stare łóżko warte 1 fl., a także kasetkę z kościoła wartą $8 \mathrm{fl}$.

\footnotetext{
${ }^{45} 1$ łokieć gdański $=57,8 \mathrm{~cm}$.

${ }^{46} 1$ Fass $($ Faska $)=2$ Tonnen $=222,700$ litra.
} 
Dziekan kapituły dobromiejskiej dostał 6 gr, a kościelną ławkę po Katarzynie oszacowano na 1 fl. 15 gr.

Dodatkowe wydatki egzekutorów testamentu wyniosły 21 fl. 271/2 gr, a w marcu 1731 r. zapłacono jeszcze kontrybucję w wysokości dziesięciokrotnego szosu łanowego.

10 czerwca 1731 r. przełożona lidzbarskiego konwentu katarzynek Marianna Nitzsch pokwitowała odbiór z rąk dobromiejskiego dziekana Herra 66 fl. 20 gr w gotówce oraz miedzianego obrazka, co było końcowym aktem wypełnienia ostatniej woli zmarłej Katarzyny Hintzman.

Charakterystyczne cechy pisowni dokumentu

Przygotowując testament do druku zastosowano następujące zasady edytorskie: usunięto zdwojenia spółgłosek na końcu wyrazów (dt, tt, ss, tz, th, ff), ujednolicono łączną i rozdzielną pisownię wy̆razów zgodnie z zasadami współczesnego języka niemieckiego (np. so wohl = sowohl), pisownię rzeczowników dużymi literami oraz interpunkcję. Literę ",",, „ü" zamieniono zgodnie z brzmieniem fonetycznym na „i” lub „ii”. Umlauty zachowano zgodnie ze współczesną pisownią. W tekście usunięto też nieme „h” oraz „b” $\mathrm{b}^{47}$.

${ }^{47}$ Stosowano zasady zawarte w instrukcji wydawniczej: J. Schultze, Richtlinien für die äussere Textgestaltung bei Herausgabe von Quellen zur neueren deutschen Geschichte, Blätter für deutsche Landesgeschichte, Jg. 98, 1962, ss. 1-11; druk też w: Richtlinien für die Edition landesgeschichlicher Quellen, hrsg. von W. Heinemeyer, Marburg-Köln 1978, ss. 25-36. 


\title{
ANEKS ŹRÓDŁOWY
}

\author{
DOKUMENT Nr 1
}

Dobre Miasto, 23 stycznia $1731 \mathrm{r}$.

Oryg.: AAWO, Archiwum Kapituly Dobromiejskiej, Dok. D.M. J 43a, Skład$k a$ papierowa czterostronnicowa o wzmiarach $19,5 \times 30 \mathrm{~cm}$, nienumerowana, zapisana na 4 stronach, papier pożółkły, atrament koloru czarnego, język łaciński i niemiecki.

\section{In Nomine Domini Amen}

Per praesens publicum instrumentum cunctis pateat evidenter et sit notum; Ouomodo Anno a Nativitate Domini Nostri JESU Christi, millesimo septingentesimo trigesimo primo, Indictione Romanae IX, Pontificatus Serenissimi Domini nostri, Domini Clementis Divina Providentiae Papae Ejus Nominis XII Anno Primo, die vero 23 Mensis Januarii, Guttstadii: in mei notarii publici testiumque infrascriptorum praesentia personaliter constituta in Domo Mansionis suae Virtuosa Virgo Catharina Hintzmanin, p[iae] d[efuncti] olim Spectabilis Domini Georgii Hintzman Proconsulis Guttstadiensis filia relicta, aetatis suae 68 annorum $^{48}$, aegra licet corporemente tamen sana et integra, palam sponte, libere et per expresseum recognovit, qualiter ipsa ultimam suam voluntatem, jam alias sub die 20 Novembris Anno praeterlapso 1730, itidem coram me declaratam et a me in seorsivo folio fideliter connotatam, in omnibus punctis, clausulis et articulis universis ratam gratamque haberi velit. Cuius quidem dispositionis et ultimae voluntatis suae tenor sequitur et est talis.

Anno 1730 die 20 Novembris in Guttstadt

Hatt Jungfrau Catharina Hintzmanin mich an disbenandtin zu sich beruffen lassen und mich gebittin auf ihrem Kranckenbett, sowohl Ihre Schulden als auch Ihren letzten Willen, wie sie es mit Ihrer übrigen wenigen Verlassenschafft nach Ihrem Tod, nach Abzug der Schulden wolle gehalten haben, zu verzeich-

${ }^{48}$ Katarzyna przeżyła sześćdziesiąt siedem lat oraz dziewięć i pół miesiąca. 
nen; mich dabei bittende, das ich solches gantz geheim halten möchte bis nach Ihrem Tode um hierdurch alle Importunität und Missvergnügen Irer Freunden zu verhinderen; Wie sie dan wohlbedächtlich und bei gutter Vernunfft also abgesagt:

Ihre Schulden

Der Frauen Zimmermanin neben Abrechnung des Holtzgeldes 7 Mk 4 Gr. für das in Martini verflossene Jahr restiret Mk 37 Gr 16

Herren Filitz Mk. 8 Gr. 6

Herren Wagner Mk. 8 Gr. 11

Meister Bonek Mk. 12

Meister Thiel Becker Mk. 5 Gr. 14

Nach der Seiligen Ursula Thum Köchin ihrem Bruder zu Minsterberg Mk. 14 Gr. 2

Catharina Grünhoffsche Mk. 14

Der Nickelsche vom Hausberg Mk. 13 Gr. 10

Summa der Schulden Mk. 113 Gr. 19

Nach Ábzug dieser Schulden verordnet Jungfrau Catharina also:

Zum Begräbnüss in hiesiger Kirchen Mk. 150

Der hiesigen Collegiatkirche zur Zierath Mk. 100

In Sante Nicolai Kirch alhier zum Bau Mk. 50

In die Schönwiesche Capell Mk. 50

Nach Crossen Mk. 50

In dass Ehrwürdige Convent nach Wormdit Mk. 100

In das Ehrwürdige Convent nach Heilsberg Mk 100

In das Wartenburgschen Convent Mk 50

In das Springbornsche Convent Mk 36

Dem Ehrwürdige Herren Gerigk Beneficiato alhier Mk 50

Item demselben den Kasten auch 2 zinnerne Schusselen mit breitem Rand.

Der Frauen Dröhersche Ertmansche Mk 50

Item derselben ein Tiegelchen

Dem Herren Ott Mk. 30

Meister Dittloff Mk. 30

Der Frauen Joseph Langsche Mk. 30

Jungfrauen Catharina Grunhoffsche Mk. 30

Item derselben den Heer Kessel vom grossem Eimer und ein Tiegelchen.

Frauen Gertrudis Böhmsche Mk. 12 
Item den Heerdsessel von 2 Eimeren und Tiegelchen.

Der Frauen Muhmen Sophiae von Saurbohm Mk. 60.

Item derselben 3 Beth, 3 zinnerne Schüsselen und das übrige Leinenzeug.

Unter die armen auszutheilen bei dem Begräbnüss Mk. 12.

In des heilsbergschen Convents Capell, dass kleine kupfferne Bildschen, darauf die Teller Seeligste Jungfrau mit dem Kindlein Jesus auf einer Seiten und der S. Michael auf der anderen Seiten.

In des wormdittschen Convents Capell das Bild der Tellerseit Jungfrauen mit dem Kindlein Jesu.

In die Schönwiesche Capell 2 Bilder, Christi und Mariae.

Im übrigen setzet sie zum Erben die hiesige Collegiatkirche, dergestalt, dass für Ihre Seel, wie auch Ihrer Eltern und Anverwandten Helige Messen möchten gelesen werden oder auch zur Verbesserung derer Beneficien für wetche die Ehrwürdige Herren Beneficiati bei hiesiger Collegiat Kirchen nicht ${ }^{49}$ zulängliche Bezahlung haben, damit sie eine Collegiat in selbigen Beneficien für die Seel Catharinae, wie auch Thrêr Elteren und Anverwandtēn einlegen oder wie es mir als hiesigem Decano am besten wird geduncken.

Das dieses Ihr letzter und eigentlicher Willen sei, hat Jungfrau Catharina Hintzmanin abermahlen und//von neuem erklärt, auch in Gegenwart des Ehr[würdigen] Herren Joseph Gerigk Beneficiati alhier und des Ehrenvesten Wohlweisen Herren Sylvestri Geritz Bürgermeisters, als hirzu ausdrücklich erbittenen Zeigen abgesagt den 23 Januarii Anno 1731. Mich hiebei inständigst bittend bestmöglichst zubesorgen, das dieser Ihr letzter Willen in allen und jeden Stücken vollkommentlich gehalten und vollzogen werde. $\mathrm{Zu}$ dessen mehrerem Glauben habe mich eigenhändig unterschrieben. So geschehen in Guttstadt die 23 Januarii Anno 1731.

Franciscus Ignatius Herr Decanus Canonicus Guttstadiensis

Publicus Sanctae Authorithatae Apostolicae Notarius

manu propria

Acta sunt haec Guttstadii Anno die quibus supra

Praesentibus Admodum Reverendo Domino Josepho Gerigk Beneficiato Ecclesiae Collegiatae Guttstadiensi et Spectabili Domino Sylvestro Geritz Proconsule Guttstadiensi uti Testibus ad praemissa specialiter rogatis et adhibitis.

Et quia ego Franciscus Ignatius olim Beniamin Herr Publicus Sacrae Authorithatae Apostolica Notarius praemissam dispositionem ultimate voluntatis de ore proprio praefatae Virginis Catharinae Hintzmanin excepi omniaque; ea

\footnotetext{
${ }^{49}$ a-a wyrwana dziura w tekście.
} 
sic fiery vidi et audivi prout acta esse enarrantur; idcirco eandem dispositi onem ad acta notariatus mei publici recepi ac praesens desuper instrumentum publicum confeci, non neque cognomina ac signo meis solitis, quibus in similibus utor communivi in fidem et robur praemissorum.

Idem qui super

Franciscus Ignatius Herr

Publicus Sanctae Authorithatae Apostolicae Notarius

manu propria

Anno 1731 die 27 mensis Aprilis Smolainii coram Celsissimo Principe Illustrissimo et Reverendissimo Domino Louerdinerio judicialiter productum

Antonius Ignatius Hoffmann

Causarum Curiae Episcopalis Notarius

manu propria

\section{DOKUMENT $\mathrm{Nr} 2$}

Smolajny, 27 IV $1731 \mathrm{r}$.

Oryg: AAWO, AKD, Dok. D.M. J 43b, składka papierowa czterostronnicowa o wymiarach 19,5 × $30 \mathrm{~cm}$, nienumerowana, zapisana na pierwszej stronie, papier pożółkły, atrament koloru czarnego, język łaciński.

Anno Millesimo septigentisimo trigesimo primo die vero veneris vigesima septima mensis Aprilis Smolainii in Palatio Episcopali.

Coram Celsisimo Principe Illustrissimo et Reverendissimo Domino Domino Christophoro Andrea Comite in Slupow Szembek, Episcopo Varmiensi et Sambiensi S[acrae] R[omani] I[mperii] Principe Terrarum Prussiae Praeside in causa et actione judiciaria inter Perillustrem Admodum Reverendum Franciscum Ignatium Herr Decanum Canonicum nomine Ecclesiae Collegiatae Guttstadiensis agentem ab una et consangvineos $\mathrm{p}$ [iae] d[efuncti] Catharinae Hintzmanin ab altera, partibus occasione testamenti ab eadem $p$ [iae] d[efuncti] Catharina post varia legata etiam in favorem dicta Ecclesiae Collegiatae conditi in termino hodierno ex litteris cridae proveniente comparentibus.

Celsissimus Princeps Illustrissimus et Reverendissimus Dominus, Dominus Episcopus Supramemoratus et Iudex, sedens. Auditis tam ex parte agente, quam ex adverso comparente illationibus et controversiis, verbo in hac causa factis; quandoquidem Testamentum p[iae] d[efuncti] Catharinae Hintzmanin a consaguineis ejusedem $\mathrm{p}$ [iae] d[efuncti] Testatoriis oppugnatum, a Nota- 
rio Apostolico publico, adhibitis duobus Testibus et quidem Spectabili Consule loci, scabinos et notarium, alias adhiberi solitos, sufficienter representante, valide conditum fuit, haeredibus quoque, qui de Iure Culmensi, ut pote non necessarii et remotiores fratribus et sororibus ad legitimam minime vocantur in titulum legitimate aliqua legata in eodem inscripta sunt. Idem Testamentum ad pias causas conditum, non derogando praxi reundum Jus Culmense condendi ejusmodi Testamenta praescriptae approbandum et confirmandum esse censuit, prout authoritate suprima approbavit et confirmavit, idemque exequendi facultatem tribuit. Decreti praesenti vigore.

Ex Actis Causarum Curiae Episcopalis Varmiensis extractum et Sigillo praesentata Suae Celsitudinis Illustrissimae communitum.

Antonius Ignatius Hoffmann

Causarum Curiae Episcopalis Notarius $s^{50}$ manu propria ${ }^{51}$

\section{Dokument Nr 3}

post 3 II $1731 \mathrm{r}$.

Oryg: AAWO, AKD, Dok. D. M. J 43c, f. 1-4: Rachunki i rozliczenia po śmierci Katarzyny Hintzman z Dobrego Miasta, Dokument złożony z 6 kart, zapisany na 9 stronach $w$ języku niemieckim i łacińskim. Pierwsza strona o wymiarach $9,5 \times 30 \mathrm{~cm}$, pozostałe 6,5 $\times 9 \mathrm{~cm}$. Atrament koloru czarnego, wyblakky, pismo neogotyckie, stan zachowania dobry.

[k.1] Percepta et exposita post p[iae] d[efuncti] Virt[uosam] Virginem Catharinam Hintzmanin, quae pie in Domino obiit die 3 Februarii Anno 1731, Guttstadii

\begin{tabular}{|l|c|c|c|}
\hline Percepta & Flor. & Gr. & Den. \\
\hline In parata pecunia & 7 & 19 & 9 \\
\hline Ex divendito agro Lindenborn $^{52}$ resta & & & \\
\hline
\end{tabular}

${ }^{50}$ Słownik Biograficzny Kapituły Kolegiackiej, s. 63: Hoffman Antoni Ignacy (1699-1760), rodem z Lidzbarka Warmińskiego, w 1731 notariusz biskupi, 11 IV 1733 otrzymał inwestyturę na honorowego kanonika dobromiejskiego.

${ }^{51}$ Po lewej stronie odciśnięta pieczęć biskupia, częściowo uszkodzona.

${ }^{52}$ Lindenbrunn koło Dobrego Miasta, por. przypis 37. 


\begin{tabular}{|l|c|c|c|}
\hline $\begin{array}{l}\text { Ex divendito medio manso Spectabili Domino Sylvestro Geritz proconsuli } \\
\text { Guttstadiensi }\end{array}$ & 800 & & \\
\hline Ex divenditis rebus D. Gregorio Ott & 9 & 3 & \\
\hline D. Josepho Lang & 17 & 17 & \\
\hline Joanni Dittloff & 26 & 3 & \\
\hline Viduae Sophiae ex Sauerbohm & 10 & 15 & \\
\hline Pro veste antique simplici & & 24 & \\
\hline Pro forcipes & & 6 & \\
\hline Pro aromatibus & & 6 & \\
\hline Summa perceptorum & 932 & 23 & 9 \\
\hline
\end{tabular}

\section{Exposita}

\begin{tabular}{|l|c|c|c|}
\hline In exsolutionem creditorum & Fl. & Gr. & Den. \\
\hline Admodum R[everendo] Petro Elert Capellano Guttst[adiensi] & 8 & & \\
\hline Viduae Zimmermanin ${ }^{53}$ & 25 & 6 & \\
\hline Spectabili Domino Joanni Filitz & 5 & 16 & \\
\hline Spectabili Domino Petro Wagner & 8 & 21 & \\
\hline Josepho Bornek panioni & 3 & 24 & \\
\hline Joanni Thiel pistori & 9 & 12 & \\
\hline $\begin{array}{l}\text { Adalberto German Colono Münsterbergensi fratri piae defuncti Ursulae } \\
\text { coctricis olim Venerabili Collegii Guttstadiensi }\end{array}$ & & & \\
\hline Catharinae Grunhoffsche & 9 & 10 & \\
\hline Magdalenae alias Nickelsche ex Hausberg & 9 & & \\
\hline Viduae Catharinae Rautenbergin & 6 & & \\
\hline Viduae piae defuncti Andrae Schipper & 1 & 7 & \\
\hline Joanni Dittloff pro censu mansionis & 27 & & \\
\hline Joanni Wagner & 1 & 18 & \\
\hline Viduae Dorotheae Berendtin & 1 & 15 & \\
\hline Spectabili Domino Joanni Merten & & 18 & \\
\hline Viduae Perikettin & & 18 & \\
\hline Viduae Ertmansche & 1 & 2 & \\
\hline Latus facit & 123 & 17 & $9 / /$ \\
\hline [k. 1v] In Legata & & & \\
\hline Pro sepultura Ecclesia Collegiate & 100 & & \\
\hline Ecclesiae Collegiatae pro ornate & 66 & 20 & \\
\hline Oratorio S. Nicolai ${ }^{54}$ pro fabrica & 33 & 10 & \\
\hline Capellae Schönwiesensi & & \\
\hline
\end{tabular}

${ }^{53}$ Laurentius Zimmerman 1749, 1751, 1753, 1754, 1755 (APO, 1414/1, 2, Magistr. Guttst.); starszy ławy do 15 III 1758 (A 59, k. 127v).

${ }^{54}$ Kościół zbudowany w latach 1736-1741. 


\begin{tabular}{|c|c|c|c|}
\hline Ecclesiae Crossensi & 33 & 10 & \\
\hline Conventibus Wormdittensi & 66 & 20 & \\
\hline Heilsbergensi & 66 & 20 & \\
\hline Wartenburgensi & 33 & 10 & \\
\hline Springbornensi & 24 & & \\
\hline Reverendissimo Domino Josepho Gerigk Beneficiato Guttst[adiensi] & 33 & 10 & \\
\hline Viduae Tornatrici Ertmansche & 33 & 10 & \\
\hline Domino Gregorio Ott & 20 & & \\
\hline Joanni Dittloff & 20 & & \\
\hline Domini Josephi Lang uxori & 20 & & \\
\hline Virgini Catharinae Grünhoffsche & 20 & & \\
\hline Gertrudi Böhmsche & 12 & & \\
\hline Viduae Sophiae ex Saurbohm & 40 & & \\
\hline Inter pauperos in sepulture distribute & 8 & & \\
\hline Scriba cancellariae circa approbationem testamenti & 5 & 6 & \\
\hline Latus facit & 669 & 6 & \\
\hline Latus anterius & 123 & 17 & 9 \\
\hline \multicolumn{4}{|l|}{ His additur contributione in Martio de medio manso } \\
\hline Summa omnium expositorum & 793 & 23 & 9 \\
\hline $\begin{array}{l}\text { Deductis expositis a perceptis restant pro haerede ecclesia in auctionem } \\
\text { Beneficiorum }\end{array}$ & 139 & NSS & SI \\
\hline $\begin{array}{l}1731,10 \text { Julii De hac resta flor. } 139 \text { deti sunt pro auctione Beneficii Steinsoniani }{ }^{55} \\
\text { pro imponenda collecta pro animae } \mathrm{p}[\mathrm{iae}] \mathrm{d}[\mathrm{efuncti}] \text { Catharinae }\end{array}$ & 66 & 20 & \\
\hline $\begin{array}{l}\text { Item pro } 4 \text { missis per annum an eodem beneficiate pro anima Catharinae, } \\
\text { eiusque parentum et consangvineorum absolvendis }\end{array}$ & 40 & & \\
\hline \multicolumn{4}{|l|}{$\begin{array}{l}\text { 1731, } 14 \text { Julii Pro auctione Beneficii Knoblochiani }{ }^{56} \text { pro imponenda } \\
\text { collecta pro anima p]iae] d[efuncti] Catharinae }\end{array}$} \\
\hline Facit & $139 / /$ & & \\
\hline \multicolumn{4}{|l|}{$\begin{array}{l}\text { [k. 2.] Specificatio derer verlassenen Mobilien Seeligen Jungfrauen } \\
\text { Catharinae Hintzmanin }\end{array}$} \\
\hline \multicolumn{4}{|l|}{ Drei Unterbette mit weissem Bezug } \\
\hline \multicolumn{4}{|l|}{ Ein Zudeck mit buntem Bezug } \\
\hline \multicolumn{4}{|l|}{ Acht Kiess 6 mit Bezug, 2 ohne Bezug } \\
\hline \multicolumn{4}{|l|}{ Zwey alte Leinwandtssbett } \\
\hline \multicolumn{4}{|l|}{ Zwei weisse Lacken } \\
\hline Ein grosses ausshengend Lacken & & & \\
\hline
\end{tabular}

${ }^{55}$ Słownik Biograficzny Kapituły Kolegiackiej, ss. 103-104: Steinsohn Zygmunt (Steinsson) zm. 1643, pochodził z Barczewa, doktor obojga praw, 31 I 1607 uzyskał honorowy kanonikat dobromiejski z prawem rezydencji w Dobrym Mieście od 2 VIII 1612. Ufundował w Dobrym Mieście ołtarz Św. Krzyża, a przy nim dwa beneficja (1618 i 1619).

${ }^{56}$ Iibdem, ss. 67-68. Knobloch Jerzy. Pochodził z Dobrego Miasta, w 1596 r. uzyskał honorowy kanonikat w Dobrym Mieście (instalacja 17 V 1597), w latach 1597-1606 kapłan w Lidzbarku Warmińskm, w latach 1604-1608 dziekan kapituły kolegiackiej w Dobrym Mieście. W Dobrym Mieście ufundował beneficjum Męki Pańskiej zatwierdzone 11 IV $1611 \mathrm{r}$. 


\begin{tabular}{|c|c|c|}
\hline Ein höltzerness Bett & & \\
\hline 9 Bielder & & \\
\hline 4 Kisten & & \\
\hline Ein dreikantigess Kuffer & & \\
\hline Zwey höltzern Stühl & & \\
\hline Eine Bancke & & \\
\hline 3 Scheffel Weitzen & & \\
\hline 2 Scheffel Korn & & \\
\hline Ein Crucifix & & \\
\hline Wass in denen Kiesten verschlossen ist nicht specificiret & & \\
\hline [k. 2v] Geldt Einnahm & & \\
\hline Nach ihrem Tod bei ihr befinden worden 7 Fl. 19¹/2 Gr. & & \\
\hline $\begin{array}{l}\text { Von Frauen Dorothea Behrendin wegen erkaufftem Liendenbrunnen den } \\
\text { Rest empfangen }\end{array}$ & $60 \mathrm{Fl}$. & $20 \mathrm{Gr}$. \\
\hline Summa & Fl. 68 & Gr. $91 / 2$ \\
\hline
\end{tabular}

\section{EXPOSITA}

Die 4 Februarii vor 4 Pfund Riendtfleisch a 2 Gr.per Pfund

Die 5 hujus zu Brot Item ${ }^{2}$ vor ${ }^{1 / 4}$ tel Kalbfleisch

Die 6 hujus vor 3 Pf. Riendtfleisch

Die 7 hujus vor Zartfisch

Item Baumöl vor

Item Brodt vor

Item Mielch vor

Die 8 Hujus vor Fiesch

Item Brot vor

Item die gantze Zeit hindurch weil sie gelegen 20 Stof Biehr undt vor Liecht facit Fl.

[k. 3.] Vor $16^{3 / 4}$ Pfund Wachs a 1 Fl. per Pfund

Dem Schustergewerck vor die Kartitzen 1 Pfund Wachs

Item denen selben $1 / 2$ Tonne Lautbier

Vor 6 Ehlen schwartze Bänder a 6 Gr. per Ehle

Vor die Kron

Vor dass Sarg

Vor die Grieff

Dem Todtengräber

Denen Schönfeltin vor das Umbietten und auffwarthen

Dem Wagenknecht vors Verbotten

In den Rosenkrantz vor die Kartitzen 1 Pfund Wachs

\begin{tabular}{|c|c|c|}
\hline 1 & $8 \mathrm{Gr}$. & \\
\hline & $3 \mathrm{Gr}$. & \\
\hline & $9 \mathrm{Gr}$. & \\
\hline & $6 \mathrm{Gr}$. & \\
\hline & $6 \mathrm{Gr}$. & \\
\hline & $3 \mathrm{Gr}$. & \\
\hline & $2 \mathrm{Gr}$. & \\
\hline & $12 \mathrm{Gr}$. & \\
\hline & $3 \mathrm{Gr}$. & \\
\hline $2 \mathrm{Fl}$. & & \\
\hline & $6 \mathrm{Gr}$. & \\
\hline 4 & $\mathrm{Gr} .1 / /$ & \\
\hline $16 \mathrm{Fl}$. & $22^{1 / 2 \mathrm{Gr} .}$ & \\
\hline 1 & & \\
\hline 4 & & \\
\hline 1 & 6 & \\
\hline 3 & & \\
\hline 4 & & \\
\hline 10 & & \\
\hline 3 & & \\
\hline 12 & & \\
\hline 1 & 6 & \\
\hline
\end{tabular}




\begin{tabular}{|l|c|c|c|}
\hline Item in die Schützengülde 1/2 Pfund Wachs & 15 & \\
\hline $\begin{array}{l}\text { Denen Bohnenträgeren nebst denen Kartitzenträgern 6 halb Achtel Bier a } \\
15 \text { Gr. }\end{array}$ & 3 & & \\
\hline Vorss Einschreiben in das Todtenbuch der Schützengülde & & 6 & \\
\hline Item in dass Todtenbuch dess Schustergewercks & & 6 & \\
\hline & 43 Fl. & $13^{1 / 2} \mathrm{Gr}$. & \\
\hline $\begin{array}{l}\text { [k. 3v] Denen Gesellen vor dem Begräbnüss als sie sich versammelet 2 Stof } \\
\text { Brandwein a 20 gr. }\end{array}$ & 1 & 20 & \\
\hline Vor die Kaulen an das Sarg & & 27 & \\
\hline Der Fr[au] Titiusin vor nehen und aussputzen & & $21^{1 / 2}$ & \\
\hline Zue heiligen Meess & & 18 & \\
\hline Denen Armen & 8 & & \\
\hline Fr[au] Ciemmermannin ihre Schuld bezahlet in Fl. & 25 & Gr. 6 & \\
\hline Summa & Fl. 36 & Gr. $22^{1 / 2}$ & \\
\hline
\end{tabular}

Summa perceptorum 68 Fl. 91/2 Gr. Expositorum summa 90 Fl. 7 Gr. POUNOCNV Super exposita 21 Fl. 27/2 Gr.

\begin{tabular}{|l|c|c|c|}
\hline Item der Frau von Saurbohm gezahlet & 23 Fl. & 15 Gr. & \\
\hline In Martio ein zehenfacher Schoss & & & \\
\hline $\begin{array}{l}\text { Notandum vor das Begräbnüss 42 Fl. 29 Gr., welchess nicht inferiret habe, } \\
\text { alldieweilen ess noch zu bezahlen ist. }\end{array}$ & & \\
\hline & 33 & 10 & \\
\hline & 1 & 2 & \\
\hline & 29 & & \\
\hline Nota bene Herrn Otto gezahlet 20 Fl. & 8 & & \\
\hline Super exposita 21 Fl. 27 1/2 Gr. & 20 & 27 & \\
\hline & 2 & 11 & \\
\hline Der Frauen von Saurbohm gezahlet 23 Fl. 15 & 42 & 29 & \\
\hline Dem Herrn Otto gezahlet 10 Fl. 27 Gr. & 1 & $71 / 2$ & \\
\hline Summa & F. 56 & $91 / 2 \mathrm{Gr}$. & \\
\hline [k. 4v] Meister Joannes Dittloff hat angenommen: & & & \\
\hline Einen Peltz a & $3 \mathrm{Fl}$. & & \\
\hline Einen Rock nebst dem schwartzen Futterhemd & 9 & & \\
\hline Ein buntess Ermelwiestchen a & & 15 gr. & \\
\hline Ein Tiegelchen a & & $18 \mathrm{Gr}$. & \\
\hline Ein schwartzess Schortztuch a & $1 \mathrm{Fl}$. & $15 \mathrm{Gr}$. & \\
\hline Ein Mörselchen & 3 & & \\
\hline Eine ziennerne Butterbiechss & & 21 & \\
\hline
\end{tabular}




\begin{tabular}{|c|c|c|}
\hline Item ein presteisen nebst dem Boltz facit & $18 \mathrm{Fl}$. & $9 \mathrm{Gr}$. \\
\hline Herrn Otto hatt angenommen: & $1 \mathrm{Fl}$. & $15 \mathrm{Gr}$. \\
\hline Eine Laterne a & & $18 \mathrm{Gr}$. \\
\hline Ein Weinwasserfäschen nebst 4 ziennenen Löffel & & $18 \mathrm{Gr}$. \\
\hline Ein ziennerness Schiesselchen & & $12 \mathrm{Gr}$. \\
\hline Facit & Fl. 1 & Gr. 18 \\
\hline Ein sielberness Agnuss Dei & 1 & \\
\hline 2 Scheffel Korn a 1 Fl. & 2 & \\
\hline \multirow[t]{2}{*}{ Vor 2 Halbe Thonnen u[nd] 2 Höltzerne Stühl } & 1 & \\
\hline & $5 \mathrm{Fl}$. & $18 \mathrm{Gr}$. \\
\hline Vor den alten Kasten & 2 & \\
\hline Vor den beschlagenen Kuffer & 1 & $15 \mathrm{Gr}$. \\
\hline Summa & $9 \mathrm{Fl}$. & $3 \mathrm{Gr}$. \\
\hline Spectabili Geritz 2 Stoff Kümmel a 3 Gr. & & $6 \mathrm{Gr}$. \\
\hline \multicolumn{3}{|l|}{ Meister Joannes Dittloff: } \\
\hline Eine Brähmenmietze & 3 & \\
\hline Ein holtzerness Beth & 1 & $24 \mathrm{Gr}$. \\
\hline 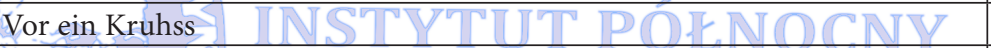 & & 9 \\
\hline & 12 \\
\hline \multirow{2}{*}{\multicolumn{2}{|c|}{\begin{tabular}{|l|l|} 
Meister Dittloff an Sachen empfangen $G+C G H$ & $25 \mathrm{Fl}$ \\
Item vor 4 Pfund Talck & \\
\end{tabular}}} & $9 \mathrm{Gr}$. \\
\hline & & $24 \mathrm{Gr}$. \\
\hline Summa o & $26 \mathrm{Fl}$. & $3 \mathrm{Gr} . / /$ \\
\hline [k. 5] Herr Josephus Lang vor 2 Beth unnd 4 Kiessen & $7 \mathrm{Fl}$. & \\
\hline Item $23 / 4$ tel. Sch[effel] Weitzen a 54 Gr. & $4 \mathrm{Fl}$ & $281 / 2 \mathrm{Gr}$. \\
\hline Item vor einen Durchschack & & $12 \mathrm{Gr}$. \\
\hline Vor Glässer & & 15 \\
\hline Vor einen Rost & & 18 \\
\hline Vor den Bettsack & & 18 \\
\hline Vor das Spiegelchen & & 6 \\
\hline Vor ein altess Spienrad & & 24 \\
\hline Vor eine messiengss Stertze & & 6 \\
\hline Item eine Bäncke & 15 & $71 / 2$ \\
\hline Vor dass Mäntelchen & 2 & $91 / 2$ \\
\hline Summa & $17 \mathrm{Fl}$. & $17 \mathrm{Gr}$. \\
\hline Anna vor den blauen Rock & & 24 Gr. \\
\hline Herr Wessler vor die $<$ Kuen $>$ zang & & 6 \\
\hline $\begin{array}{l}\text { Die Frau von Saurbohm hatt angenommen } 4 \text { schlechte Kiessen, auch ein } \\
\text { dergleichess Bett vor }\end{array}$ & 1 Fl. & \\
\hline Den Kasten auss der Kirch vor & 8 & \\
\hline Von Ihro Gnaden Herrn Decano empfangen & 6 & \\
\hline Vor die Sietzbancke & 1 & 15 \\
\hline Summa & $16 \mathrm{Fl}$. & $15 \mathrm{Gr} . / /$ \\
\hline
\end{tabular}


[k.5v.] Ich Endes benannte, gebe hiemit zu erkännen, dass ich von dem Hochwürdigen Genädigen Herren Franciscus Herr Tumherr zu Guttstadt richtig empfangen hab 66 Fl. a 20 Gr. nebst einem Kupfren Bield, welches die zu Gott ruhende Seelige Jungfrau Catharina Hientzmanin uns vermachet hat, empfangen Anno 1731 den 10. Junius.

\author{
Marianna Nitzschin \\ Matrin dess Heilssbergschen Convents//
}

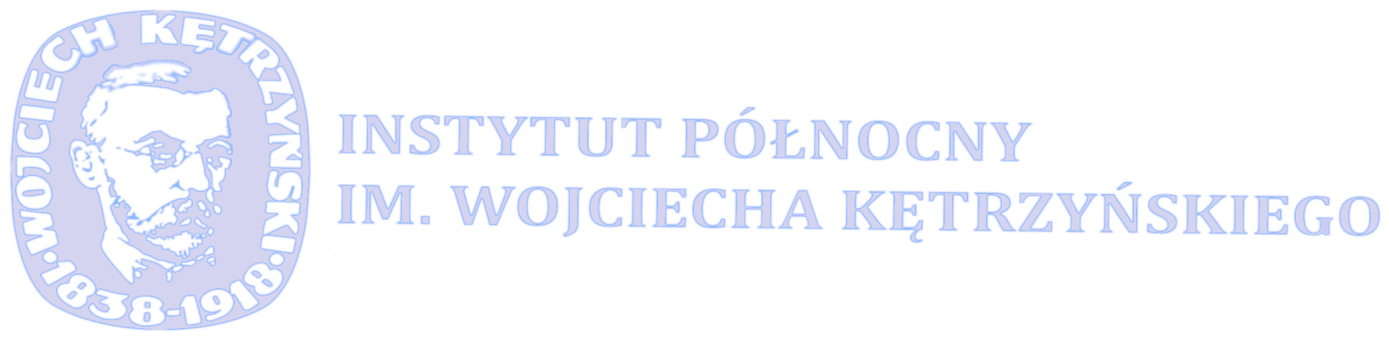

